\title{
Education Qualification for Professional Development of Javanese Language Teachers in East Java: A Case Study
}

\author{
Mintowati \\ Universitas Negeri Surabaya \\ Surabaya, Indonesia \\ mintowati@unesa.ac.id \\ Darni \\ Universitas Negeri Surabaya \\ Surabaya, Indonesia
}

\author{
Udjang Pairin M. Basir \\ Universitas Negeri Surabaya \\ Surabaya, Indonesia \\ Budi Nuryanto \\ Universitas Negeri Surabaya \\ Surabaya, Indonesia
}

\begin{abstract}
In improving quality of learning, increasing the teachers' education qualification by attending postgraduate level is highly required. The study is intended to describe the interest of prospective students of Master's Degree program, particularly majoring in Javanese Language Education. In addition, this study aims to describe the user's responses towards the prospective graduates majoring on Javanese Language Education. This is a qualitative research with the subjects involved consisted of three elements, namely student alumni of the Javanese Language Education study program, Department of Education at city and provincial levels in East Java, and universities with Elementary Teacher Education study programs. Data collection was done by questionnaire and documentation technique and analyzed by using descriptive technique. The results showed that the teacher qualification holding graduate degree on Javanese Language Education is needed, and positive attitudes were shown by graduates majoring on Javanese Language Education, especially in East Java. Almost all respondents involved stated very high scale of support for the qualification. Relevant stakeholders, in addition, also expressed positive attitudes towards the improvement of Javanese language teachers' education qualifications in East Java.
\end{abstract}

Keywords-teacher qualification; graduate education; alumni; stakeholders

\section{INTRODUCTION}

With the very tight competitive labor market, many university graduates are not able to get a job, or else, they may get the job which is not in line with their expertise and qualifications. According Alfini[1], current qualification and quality workers in the area of education are considered having low competence, while on the other hand, service users (relevant stakeholders) expect human resources and candidates with high quality. A research conducted at research-based university, including State University of Surabaya, there have been several programs aimed at increasing the qualification of human resources to human resources to meet the market's demand [2]. Therefore, it is necessary to have a grand design for quality human resources engineering in Indonesia through considering excellent and measurable planning, implementation and evaluation with global competitiveness. It is expected that the grand design may produce and change the paradigm of human resource quality improvement in Indonesia with the changing and dynamic world of science and technology in the $21^{\text {st }}$ Century. In addition, it is believed that the increase of professionalism of the human resources may improve the performance quality of the higher education institutions [3].

Given the growing awareness of the importance of improving the competence with further study along with the high interest of the graduates majoring on Javanese Language Education study program to continue their study to the Master's Program, the prospective students has increased by an average percentage of about $15 \%$. For this matter, the establishment of new graduate programs at state universities, e.g. State University of Surabaya, which concentrates on Java Language Education is very urgent to do. At State University of Surabaya, the establishment of Master's Degree on Local Language and Literature should be rooted from the existing graduate study program at the university, namely Graduate Program on Indonesian Language and Literature. It is believed that the establishment of Master's Degree on Javanese Language Education is feasible to provide opportunity for the teachers to improve their teaching expertise and professionalism. It is stated that teachers with the higher qualification of their education (e.g. teachers with Master's degree) have effects on their self-concept and work motivation [4]

Increasing the teacher's competence should be done and part of the government's commitment to improve the quality of education. The development of graduate programs is basically part of the government's program on developing national curriculum for higher education named national qualification platform of Indonesia (known as KKNI 
Curriculum); the qualifications are arranged up to $8^{\text {th }}$ level as the highest level of qualification (Director General of Higher Education, 2011) [5]. Each level has a description on the learning outcomes of the courses in accordance with the expected qualifications. Qualification levels are generated through formal education can be synchronized with the level of expertise in the field of work. Based on the results of the forum-group discussion (FGD) between the principals of the Local Languages, Education Study Programs or equivalent in 2016 was formulated using the profiles and learning achievements of the study programs or equivalent. The profiles of the graduates either as educators, researchers and instructors in the fields of local language, literature, and cultural studies should embed the learning achievements which include attitudes, knowledge, general and specific skills upon the study program [6].

In confirming the proposal for improving the human resources in the area of Javanese language education as well as the establishment of continuing study programs for the teachers, several aspects that were focused on were: 1) the interests of prospective students in the Javanese language education, and 2) the responses of the human resource users in the area of Javanese Language education. These are fundamental issues in developing human resource development plan in the area of Javanese language education, especially in East Java.

\section{METHOD}

This is a qualitative research in which the researchers have been engaged closely with the research participants as advised by Creswell [7]. This study analyzed the phenomena, perceptions, and attitudes of the people in groups about the perceptions and thoughts on the graduates of Javanese Language Education study programs and graduates users. The information obtained would be very useful as a foundation for the establishment of the Master's Degree on Javanese Language Education.

There were three main subjects involved in this study, namely 1) graduates (undergraduate program) majoring on Department of Local Language Education. There were 1320 alumni invited to participate in this study; 2) the users or graduates majoring on Master's Degree on Local Language Education, i.e. Department Education both city and provincial offices and universities with Local Language Education Program and Elementary Teacher Education study programs; and 3) partner universities which have been involved in formulating the national qualification platform curriculum, particularly prominent universities in Java, State University of Solo and State University of Yogyakarta.

Data collection employed were questionnaire and documentation methods. The questionnaires were designed in form of Google Form and distributed to the research subjects through social media platform, e.g. WhatsApp group consisting of alumni, teachers, and active students majoring on Javanese language education. The questionnaire was to collect data from undergraduate graduates and work as teachers as well as given to active students that were attending Bachelor's
Degree on Javanese Language Education study program as teacher candidates. In addition, the questionnaire in form of letter of support was also sent to relevant stakeholders such as the Head of Department of Education for both city and provincial offices, school principals of junior and senior high schools as the users of the graduates majoring on Javanese Language Education. Furthermore, documentation was required from the partner universities in relation with the curriculum preparation which requires the relevant curriculum the partner universities. Data analysis was conducted descriptively in order to obtain the description of five main issues, namely responses from prospective students, graduates users, draft of the curriculum, human resources, and the availability of facilities and infrastructure. The analytical model used was as suggested by Miles and Huberman [8] in form of an interactive analysis model. The interactive model consists of three parts, namely data reduction, data presentation, and conclusion.

\section{FINDINGS AND DISCUSSION}

A. Prospective Students' Attitudes towards Master's Degree on Javanese Language Education

The Master's Degree on Javanese Language Education is part of the Postgraduate Program of State University of Surabaya. Prospective students of the Master's Degree on Local Language Education of State University of Surabaya consists of two groups: 1) students who are attending Bachelor's Degree on Javanese Language Education program at State University of Surabaya and other universities in East Java and surrounding areas; and 2) students alumni majoring on Local Language Education, both who are now working as teachers of Javanese Language and who have not worked yet.

100 participants responded to the online questionnaire through Google Form distributed through social media platform, e.g. WhatsApp groups. The questionnaires were distributed and open for about 10 days within 6-17 November 2017. The participants actively involved in filling the questionnaire.

\section{Initial Responses from Prospective Students of Master's \\ Degree on Javanese Language Education from active \\ students studying at State University of Surabaya}

There were twenty questions that were distributed and addressed by prospective students of Master's Degree on Javanese Language Education study program who are now attending undergraduate program at State University of Surabaya. Detail description of the responses are as in the following table. 
TABLE I. Responses from Prospective Students of Master's Degree on Javanese Language Education from active students

\begin{tabular}{|c|c|c|c|c|}
\hline \multirow[b]{2}{*}{ Ref. } & \multirow[b]{2}{*}{ Statements } & \multicolumn{3}{|c|}{ Responses } \\
\hline & & $\begin{array}{c}\text { Agree } \\
(\%)\end{array}$ & $\begin{array}{l}\text { Partly } \\
\text { Agree } \\
(\%)\end{array}$ & $\begin{array}{c}\text { Disagree } \\
(\%)\end{array}$ \\
\hline 1 & $\begin{array}{l}\text { State University of Surabaya is one } \\
\text { of the Teacher Training Institutes } \\
\text { (TTIs) in Indonesia which is } \\
\text { qualified to conduct education for } \\
\text { prospective teachers on } \\
\text { undergraduate, Master's, and } \\
\text { doctoral levels. }\end{array}$ & 100 & 0 & 0 \\
\hline 2 & $\begin{array}{l}\text { Postgraduate Program of State } \\
\text { University of Surabaya is one of } \\
\text { the qualified educational } \\
\text { institutions to educate Master's } \\
\text { Degree on Education. }\end{array}$ & 100 & 0 & 0 \\
\hline 3 & $\begin{array}{l}\text { Indonesia, especially East Java, } \\
\text { Central Java, and Special Region } \\
\text { of Yogyakarta, requires Master's } \\
\text { Degree on Javanese Language } \\
\text { Education }\end{array}$ & 100 & 0 & 0 \\
\hline 4 & $\begin{array}{l}\text { State University of Surabaya is one } \\
\text { of the TTIs responsible for } \\
\text { implementing Master's Degree on } \\
\text { Javanese Language Education }\end{array}$ & 100 & 0 & 0 \\
\hline 5 & $\begin{array}{l}\text { In my opinion, State University of } \\
\text { Surabaya is one of the TTIs which } \\
\text { are qualified and able to establish } \\
\text { Master's Degree on Javanese } \\
\text { Language Education study } \\
\text { program. }\end{array}$ & 100 & 0 & 0 \\
\hline 6 & $\begin{array}{l}\text { Javanese Language subject should } \\
\text { be taught at both elementary and } \\
\text { secondary schools levels in } \\
\text { Indonesia. }\end{array}$ & 100 & 0 & 0 \\
\hline 7 & $\begin{array}{l}\text { Javanese Language subject is } \\
\text { necessary to be taught at } \\
\text { elementary and secondary schools } \\
\text { levels }\end{array}$ & 100 & 0 & 0 \\
\hline 8 & $\begin{array}{l}\text { The teaching of Javanese Language } \\
\text { is one effort to preserve cultural } \\
\text { herritage of Indonesian nation. }\end{array}$ & 100 & 0 & 0 \\
\hline 9 & $\begin{array}{l}\text { The teaching of Javanese Language } \\
\text { is one effort to prevent the } \\
\text { extinction of local languages in } \\
\text { Indonesia. }\end{array}$ & 100 & 0 & 0 \\
\hline 10 & $\begin{array}{l}\text { The teaching of Javanese Language } \\
\text { is intended to instill the local } \\
\text { wisdom of Indonesian culture. }\end{array}$ & 100 & 0 & 0 \\
\hline 11 & $\begin{array}{l}\text { The teaching of Javanese Language } \\
\text { requires professional and } \\
\text { competent educators. }\end{array}$ & 100 & 0 & 0 \\
\hline 12 & $\begin{array}{l}\text { Teachers and teacher candidates } \\
\text { for Javanese Language should } \\
\text { improve their competence in } \\
\text { pedagogy and professionalism. }\end{array}$ & 100 & 0 & 0 \\
\hline 13 & $\begin{array}{l}\text { One strategy to improve the } \\
\text { pedagogic and professional } \\
\text { competence is for teachers and } \\
\text { teacher candidates for Javanese } \\
\text { Language is by attending graduate } \\
\text { education in the area of Javanese } \\
\text { Language Education. }\end{array}$ & 99 & 1 & 0 \\
\hline 14 & $\begin{array}{l}\text { By attending Master's Degree on } \\
\text { Javanese Language Education, } \\
\text { prospective students are expected } \\
\text { to become more professional } \\
\text { educators. }\end{array}$ & 100 & 0 & 0 \\
\hline
\end{tabular}

\begin{tabular}{|l|l|l|l|l|}
\hline 15 & $\begin{array}{l}\text { By attending Master's Degree on } \\
\text { Javanese Language Education, } \\
\text { prospective students are expected } \\
\text { to become teaching material } \\
\text { developers and designers in the } \\
\text { area of Javanese Language } \\
\text { Education. }\end{array}$ & 99 & 1 & 0 \\
\hline 16 & $\begin{array}{l}\text { By attending Master's Degree on } \\
\text { Javanese Language Education, } \\
\text { prospective students are expected } \\
\text { to become researchers in the area } \\
\text { of Javanese Language Education. }\end{array}$ & 99 & 1 & 0 \\
\hline 17 & $\begin{array}{l}\text { By attending Master's Degree on } \\
\text { Javanese Language Education, } \\
\text { prospective students are expected } \\
\text { to become practitioners in the area } \\
\text { of Javanese Language Education. }\end{array}$ & 100 & 0 & 0 \\
\hline 18 & $\begin{array}{l}\text { By attending Master's Degree on } \\
\text { Javanese Language Education, } \\
\text { prospective students are expected } \\
\text { to become experts in the area of } \\
\text { Javanese Language Education. }\end{array}$ & 100 & 0 & 0 \\
\hline 19 & $\begin{array}{l}\text { By attending Master's Degree on } \\
\text { Javanese Language Education, it is } \\
\text { expected that Javanese Language } \\
\text { has stronger position among local } \\
\text { languages in Indonesia. }\end{array}$ & 100 & 0 & 0 \\
\hline 20 & $\begin{array}{l}\text { By attending Master's Degree on } \\
\text { Javanese Language Education, it is } \\
\text { expected to enrich Indonesian } \\
\text { languages, literature, and culture. }\end{array}$ & 100 & 0 & 0 \\
\hline $\begin{array}{l}\text { Percentage } \\
\text { natare }\end{array}$ & 97 & 3 & 0 \\
\hline
\end{tabular}

There were 2 students who partly agreed on the 3 statements distributed, while one respondent (out of 100) partly agreed that the Master's on Javanese Language Education is needed for teachers in improving their teaching professionalism. One respondent partly agreed that by attending graduate education in the area of Javanese Language Education, the students are able to become the developers or programmer of teaching materials in the area of Javanese Language education. Similar to attending graduate education, prospective students are expected to become researchers in the area of Javanese Language education. In Article 10 of the Law Number 14 of 2005 on Teacher and Lecturer stipulates the requirement for teachers to have competences in the area of professionalism, pedagogy, social, and personality [9]. In order to meet the professional and pedagogical competences, prospective Javanese language teachers may attend Master's degree in respective area. The answers from the respondents through questionnaire showed that graduates majoring on Javanese Language Education Study Program, who had just graduated from undergraduate program, had positive interest in improving their professional and pedagogical competences by attending Master's degree. By attending graduate schools, they might have bigger opportunities to improve linguistic and literary science of local languages as part of their expertise, joining teaching and learning activities, and conducting research to develop a thesis. Regarding this possibility, State University of Surabaya as one of the prominent TTIs in eastern and central Indonesia is eligible and has the opportunity to educate teachers in the area of Javanese Language Education from undergraduate to doctoral degrees. 
2. Responses on the Establishment of Master's Degree on Javanese Language Education (already working/teachers)

There were two respondents who stated that they partly agree on the 4 statements (of 20) that were given on the survey. Two teachers expressed their disagreement on the statement that attending graduate education would provide bigger opportunity for the prospect students to develop better teaching and material development in the area of Javanese Language education. Another more teacher declared Partly Agreement on the four statements, in specific statements numbers $1,13,17$, and 20.

TABLE II. PROSPECTIVE STUDENT'S RESPONSES ON THE

ESTABLISHMENT OF MASTER'S DEGREE ON JAVANESE LANGUAGE EDUCATION (ALREADY WORKING/TEACHERS)

\begin{tabular}{|c|c|c|c|c|}
\hline \multirow[b]{2}{*}{ Ref. } & \multirow[b]{2}{*}{ Statements } & \multicolumn{3}{|c|}{ Responses } \\
\hline & & $\begin{array}{c}\text { Agree } \\
(\%)\end{array}$ & $\begin{array}{c}\text { Partly } \\
\text { Agree } \\
(\%)\end{array}$ & $\begin{array}{c}\text { Disagree } \\
(\%)\end{array}$ \\
\hline 1 & $\begin{array}{l}\text { State University of Surabaya is one } \\
\text { of the Teacher Training Institutes } \\
\text { (TTIs) in Indonesia which is } \\
\text { qualified to conduct education for } \\
\text { prospective teachers on } \\
\text { undergraduate, Master's, and } \\
\text { doctoral levels. }\end{array}$ & 100 & 0 & 0 \\
\hline 2 & $\begin{array}{l}\text { Postgraduate Program of State } \\
\text { University of Surabaya is one of } \\
\text { the qualified educational } \\
\text { institutions to educate Master's } \\
\text { Degree on Education. }\end{array}$ & 100 & 0 & 0 \\
\hline 3 & $\begin{array}{l}\text { Indonesia, especially East Java, } \\
\text { Central Java, and Special Region } \\
\text { of Yogyakarta, requires Master's } \\
\text { Degree on Javanese Language } \\
\text { Education }\end{array}$ & 100 & 0 & 0 \\
\hline 4 & $\begin{array}{l}\text { State University of Surabaya is one } \\
\text { of the TTIs responsible for } \\
\text { implementing Master's Degree on } \\
\text { Javanese Language Education }\end{array}$ & 100 & 0 & 0 \\
\hline 5 & $\begin{array}{l}\text { In my opinion, State University of } \\
\text { Surabaya is one of the TTIs which } \\
\text { are qualified and able to establish } \\
\text { Master's Degree on Javanese } \\
\text { Language Education study } \\
\text { program. }\end{array}$ & 100 & 0 & 0 \\
\hline 6 & $\begin{array}{l}\text { Javanese Language subject should } \\
\text { be taught at both elementary and } \\
\text { secondary schools levels in } \\
\text { Indonesia. }\end{array}$ & 100 & 0 & 0 \\
\hline 7 & $\begin{array}{l}\text { Javanese Language subject is } \\
\text { necessary to be taught at } \\
\text { elementary and secondary schools } \\
\text { levels }\end{array}$ & 100 & 0 & 0 \\
\hline 8 & $\begin{array}{l}\text { The teaching of Javanese } \\
\text { Language is one effort to preserve } \\
\text { cultural herritage of Indonesian } \\
\text { nation. }\end{array}$ & 100 & 0 & 0 \\
\hline 9 & $\begin{array}{l}\text { The teaching of Javanese } \\
\text { Language is one effort to prevent } \\
\text { the extinction of local languages in } \\
\text { Indonesia. }\end{array}$ & 100 & 0 & 0 \\
\hline 10 & $\begin{array}{l}\text { The teaching of Javanese } \\
\text { Language is intended to instill the } \\
\text { local wisdom of Indonesian } \\
\text { culture. }\end{array}$ & 100 & 0 & 0 \\
\hline 11 & The teaching of Javanese & 100 & 0 & 0 \\
\hline
\end{tabular}

\begin{tabular}{|c|c|c|c|c|}
\hline \multirow[b]{2}{*}{ Ref. } & \multirow[b]{2}{*}{ Statements } & \multicolumn{3}{|c|}{ Responses } \\
\hline & & $\begin{array}{c}\text { Agree } \\
(\%)\end{array}$ & $\begin{array}{c}\text { Partly } \\
\text { Agree } \\
(\%)\end{array}$ & $\begin{array}{c}\text { Disagree } \\
(\%)\end{array}$ \\
\hline & $\begin{array}{l}\text { Language requires professional } \\
\text { and competent educators. }\end{array}$ & & & \\
\hline 12 & $\begin{array}{l}\text { Teachers and teacher candidates } \\
\text { for Javanese Language should } \\
\text { improve their competence in } \\
\text { pedagogy and professionalism. }\end{array}$ & 100 & 0 & 0 \\
\hline 13 & $\begin{array}{l}\text { One strategy to improve the } \\
\text { pedagogic and professional } \\
\text { competence is for teachers and } \\
\text { teacher candidates for Javanese } \\
\text { Language is by attending graduate } \\
\text { education in the area of Javanese } \\
\text { Language Education. }\end{array}$ & 99 & 1 & 0 \\
\hline 14 & $\begin{array}{l}\text { By attending Master's Degree on } \\
\text { Javanese Language Education, } \\
\text { prospective students are expected } \\
\text { to become more professional } \\
\text { educators. }\end{array}$ & 100 & 0 & 0 \\
\hline 15 & $\begin{array}{l}\text { By attending Master's Degree on } \\
\text { Javanese Language Education, } \\
\text { prospective students are expected } \\
\text { to become teaching material } \\
\text { developers and designers in the } \\
\text { area of Javanese Language } \\
\text { Education. }\end{array}$ & 98 & 2 & 0 \\
\hline 16 & $\begin{array}{l}\text { By attending Master's Degree on } \\
\text { Javanese Language Education, } \\
\text { prospective students are expected } \\
\text { to become researchers in the area } \\
\text { of Javanese Language Education. }\end{array}$ & 100 & 0 & 0 \\
\hline 17 & $\begin{array}{l}\text { By attending Master's Degree on } \\
\text { Javanese Language Education, } \\
\text { prospective students are expected } \\
\text { to become practitioners in the area } \\
\text { of Javanese Language Education. }\end{array}$ & 99 & 1 & 0 \\
\hline 18 & $\begin{array}{l}\text { By attending Master's Degree on } \\
\text { Javanese Language Education, } \\
\text { prospective students are expected } \\
\text { to become experts in the area of } \\
\text { Javanese Language Education. }\end{array}$ & 100 & 0 & 0 \\
\hline 19 & $\begin{array}{l}\text { By attending Master's Degree on } \\
\text { Javanese Language Education, it is } \\
\text { expected that Javanese Language } \\
\text { has stronger position among local } \\
\text { languages in Indonesia. }\end{array}$ & 100 & 0 & 0 \\
\hline 20 & $\begin{array}{l}\text { By attending Master's Degree on } \\
\text { Javanese Language Education, it is } \\
\text { expected to enrich Indonesian } \\
\text { languages, literature, and culture. }\end{array}$ & 99 & 1 & 0 \\
\hline & Percentage & 96 & 4 & 0 \\
\hline
\end{tabular}

In terms of the ratio, only $2 \%$ of the teachers as the respondents partly agreed with the statements. In addition, only four statements were being criticized, while the other sixteen statements were responded in positive attitudes; it means that only $20 \%$ were agreed partly, while the rest received positive attitudes from the teachers. It was indicated that teachers had obvious stance upon this issue as stated in the questionnaire. The results indicated that the needs for further study to graduate degrees in Javanese Language Education do have possible research and development for the teaching of Javanese Language Education. This research and development is believed to provide a room for experts to generate new theories or revise the current theory that, and 
there is a possible answer and solution for various aspects of life and pedagogy in the area of Javanese language [9].

\section{CONCLUSION}

The results showed that the attitudes of the teachers in selfdevelopment are very strong, shown by the positive responses towards the establishment of Master's Degree on Javanese Language Education, e.g. prospective students, students who are still attending undergraduates major on Javanese Language Education, and graduates or alumni who have become teachers. Almost all of the respondents give agreement with the establishment of the Master's Degree on Javanese Language Education at State University of Surabaya.

\section{ACKNOWLEDGMENT}

We would like to extend our gratitude to the Director and staffs of Postgraduate Program, Head of Master's Program on Language and Literature Education, State University of Surabaya who have facilitated this preliminary research in order to establish Master's Degree on Javanese Language Education. We also thank Head of Master's Degree on Javanese Language Education of State University of Solo and State University of Yogyakarta who have provided information about curriculum

\section{REFERENCES}

[1] Elfini, Upaya Mengembangkan Kualifikasi Akademik dan Kompetensi Guru, 2017.

[2] A. Juwariyah, Darni, Trisakti, and A. Mustofa, "The Issues on Further Studies to Ph.D Degrees: The Problems
Of Liniarity For Lecturers' Carreer Development" in International Journal of Multidisciplinary Educational Research, Volume 5, Issue 9(5), September 2016, pp. 162-182.

[3] A. Hakim, "Contribution of Competence Teacher (Pedagogical, Personality, Professional Competence and Social) On the Performance of Learning" in The International Journal Of Engineering And Science (IJES), Volume, 4, Issue 2, 2015, pp. 01-12.

[4] Ministry of Research, Technology, and Higher Education, Ministrial Regulation Number 50 of 2015 on The Establishment of Higher Education Institution in Ministry of Research, Technology, and Higher Education.

[5] I. Ayusrijuniantari, "Pentingnya Peningkatan Kompetensi Guru Dalam Pencapaian Hasil Belajar Siswa”, 2016.

[6] Directorate General for Higher Education, Policy on National Qualification Platform and Teacher Training Institutes, Jakarta: Ministry of Education and Culture, 2011.

[7] Megawati, Kerangka Kualifikasi Nasional Indonesia (Indonesian Qualification Framework). Unpublished presentation. Jakarta: Directorate for Learning and Students Affairs, Directorate General for Higher Education, 2010. pp. 3.

[8] J.W. Creswell, Qualitative Research Design (Translated by: Amad Lintang Lazuardi). Yogyakarta: Pustaka Pelajar, 2015, pp. 26.

[9] M.B. Miles, and A.M. Huberman, Qualitative Data Analysis (translated by Tjetjep Rohendi Rosidi), Jakarta: Universitas Indonesia Press, 2007. pp. 73.

[10] Law Number 14 of 2005 on Teacher and Lecturer.

[11] H. Darmadi, Metode Penelitian Pendidikan. Bandung: Alfabeta,

2011 . 